\author{
Dr Artur ZIMNY \\ Wydział Społeczno-Techniczny, Państwowa Wyższa Szkoła Zawodowa w Koninie \\ e-mail: artur.zimny@konin.edu.pl \\ ORCID: 0000-0002-8025-550X
}

DOI: $10.15290 /$ oes.2018.04.94.04

\title{
POPRAWA EFEKTYWNOŚCI KOSZTOWEJ I DYWERSYFIKACJA PRZYCHODÓW W INSTYTUCJACH SZKOLNICTWA WYŻSZEGO
}

\begin{abstract}
Streszczenie
Celem niniejszego artykułu jest przedstawienie działań zmierzających do poprawy efektywności kosztowej i dywersyfikacji przychodów w uczelniach funkcjonujących w krajach wysokorozwiniętych. $\mathrm{Na}$ podstawie analizy literatury zagranicznej, metod indukcji i dedukcji, a także w oparciu o rezultaty obserwacji polskiego systemu szkolnictwa wyższego, dokonanej w ostatnich latach przez autora, potwierdzono przyjętą hipotezę. Zgodnie z nią pomimo znaczących różnic społecznych, gospodarczych, kulturowych i politycznych między poszczególnymi krajami, wyzwania finansowe stojące przed instytucjami szkolnictwa wyższego są bardzo podobne, a doświadczenia uczelni zagranicznych mogą mieć istotne znaczenie dla polskich szkół wyższych. Wspomniane doświadczenia wskazują na konieczność wprowadzenia pewnych zmian w finansowaniu instytucji szkolnictwa wyższego w Polsce, a jednocześnie nakreślają kierunek, w którym prawdopodobnie będzie zmierzał system finansowania.
\end{abstract}

Słowa kluczowe: szkolnictwo wyższe, redukcja kosztów, źródła przychodów, systemy finansowania

\section{IMPROVING COST-EFFECTIVENESS AND REVENUE DIVERSIFICATION IN HIGHER EDUCATION INSTITUTIONS}

\begin{abstract}
Summary
The aim of this article is to present activities aimed to improving cost-effectiveness and revenues diversification in higher education institutions operating in highly developed countries. On the basis of the analysis of foreign literature, methods of induction and deduction, and basing on the results of observations of the Polish higher education system made in recent years by the author, it was possible to confirmed the adopted hypothesis, according to which, despite significant social, economic, cultural and political differences between individual countries, financial challenges faced by higher education institutions are very similar, and the experience of foreign universities can be important for Polish higher education institutions. These experiences indicate the need to introduce some changes in the financing of higher education institutions in Poland, and, at the same time, outline the direction in which the financing system is likely to be heading.
\end{abstract}

Key words: higher education, cost reduction, sources of revenue, financing systems

JEL classification: I22, I23 


\section{Wstęp}

Większa i szersza autonomia przyznana uczelniom w wielu krajach wysokorozwiniętych wygenerowała potrzebę większej odpowiedzialności i przejrzystości w wydatkowaniu środków publicznych na szkolnictwo wyższe [Askling, 1997, s. 1726]. Rządy większości krajów, nierzadko borykające się z poważnymi ograniczeniami budżetowymi będącymi następstwem kryzysu gospodarczego, zaczęły zdecydowanie naciskać na efektywne wydatkowanie środków. Obecnie od instytucji szkolnictwa wyższego oczekuje się, że będą bardziej skuteczne i wydajne we wszystkich obszarach swojego funkcjonowania. W związku z tym, uczelnie są zmuszone do poszukiwania nowych źródeł finansowania w postaci środków prywatnych. Dostosowując się do zmieniających realiów społecznych i gospodarczych, szkoły wyższe stają przed wieloma wyzwaniami, które wydają się zagrażać ich długoterminowej stabilności finansowej.

Celem niniejszego artykułu jest przedstawienie działań zmierzających do poprawy efektywności kosztowej i dywersyfikacji przychodów w uczelniach funkcjonujących w krajach wysokorozwiniętych. W artykule sformułowano hipotezę głosząca, że pomimo znaczących różnic społecznych, gospodarczych, kulturowych i politycznych między poszczególnymi krajami, wyzwania finansowe, stojące przed instytucjami szkolnictwa wyższego, są bardzo podobne, a doświadczenia zagraniczne moga mieć istotne znaczenie dla polskich szkół wyższych. Hipotezę tę zweryfikowano przy zastosowaniu następujących metod badawczych: analizy literatury zagranicznej, metod indukcji i dedukcji, a także $w$ oparciu o rezultaty obserwacji polskiego systemu szkolnictwa wyższego dokonanej w ostatnich latach przez autora.

\section{Redukowanie kosztów w instytucjach szkolnictwa wyższego}

W strukturze kosztów uczelni funkcjonujących w krajach wysokorozwiniętych dominują koszty związane z zatrudnieniem nauczycieli akademickich i pracowników niebędących nauczycielami. W 2014 r. udział tych kosztów wahał się od nieco ponad $50 \%$ na Lotwie i w Japonii do prawie $75 \%$ w Belgii i Francji. Sytuacja, w której koszty personelu systematycznie wzrastają, zmusza szkoły wyższe, w obliczu ograniczonych zasobów finansowych, do poszukiwania sposobów poprawy efektywności kosztowej. W literaturze przedmiotu oraz w cyklicznych publikacjach OECD pt. „The State of Higher Education” zwraca się uwage na trzy sposoby, a mianowicie: regulacje i zachęty rządowe, wykorzystanie technologii oraz specjalizację funkcjonalną uczelni [Glass, 2014, s. 59].

Przepisy i zachęty stosowane przez władze publiczne w odniesieniu do instytucji szkolnictwa wyższego mają charakter ogólnosystemowy i różnią się w zależności od kraju. Ich wykorzystanie w celu poprawy efektywności kosztowej jest w dużej mierze uwarunkowane relacjami istniejącymi między rządami a uczelniami, a dokładnie rzecz ujmując, zależy od stopnia, w jakim rządy mogą wywierać wpływ na szkoły wyższe. Wpływ ten jest z reguły większy w czasach kryzysu gospodarczego, gdy 
władze narzucają ograniczenia budżetowe całemu sektorowi finansów publicznych. Najlepszym przykładem są działania polegające na konstytucyjnym ograniczeniu deficytów budżetowych, które zostały podjęte w 2009 r. w Niemczech [Truger, Will 2012], a także działania na rzecz kontroli rozmiarów zatrudnienia w sektorze publicznym, rozpoczęte w 2011 r. w Irlandii [Employment..., 2011]. Zachęcanie instytucji szkolnictwa wyższego do obniżania kosztów może mieć też mniej dyrektywny charakter. Dla przykładu, rządowy plan rozwoju edukacji i badań w Finlandii na lata 2011-2016 motywował uczelnie do budowania krajowych sojuszy wspierających ich strategiczne obszary, co pozwoliłoby lepiej wykorzystać dostępne zasoby i wyeliminować sytuacje, w których takie same lub podobne przedsięwzięcia badawcze są realizowane przez kilka szkół wyższych [Promoting..., 2014]. Podobny przykład płynie z Wielkiej Brytanii, gdzie poprawy efektywności kosztowej upatruje się $\mathrm{w}$ fuzjach uczelni wspieranych za pośrednictwem państwowego funduszu rekonfiguracji i współpracy [Staying on top..., 2010, s. 41] Inne rozwiązanie, wprowadzone w Dakocie Południowej w Stanach Zjednoczonych, polega na zobowiązaniu szkół wyższych do pokrywania wszelkich dodatkowych kosztów operacyjnych wynikających z powiększenia powierzchni kampusów, co w konsekwencji motywuje do racjonalizacji decyzji dotyczących budowy nowych obiektów [Improving..., 2013, s. 21].

Drugim sposobem ograniczania kosztów, a jednocześnie zwiększania dostępności szkolnictwa wyższego jest wykorzystanie technologii. Na możliwości płynące z szerokiego zastosowania nowoczesnych rozwiązań technologicznych zwraca uwagę wielu autorów, sygnalizując, że kluczowe znaczenie dla skutecznego wdrażania technologii w uczelniach ma wsparcie ze strony władz publicznych [Salmi, 2009, s. 285322; Sheets i in., 2012; Bowen, 2013]. Niewattpliwie technologia pozwala obniżyć koszty administracyjnej obsługi procesu kształcenia, w szczególności poprzez zautomatyzowanie niektórych procedur, poprawę jakości danych dotyczących studentów, zwiększenie wydajności usług bibliotecznych itp. Poza tym, rozwiązania technologiczne pozwalaja ograniczyć nakłady inwestycyjne na nowe obiekty dydaktyczne, pomagają rozszerzyć i ulepszyć programy kształcenia, na przykład za pomocą masowych otwartych kursów online (MOOCs), a także umożliwiają szybszą realizację programów kształcenia, chociażby przez wcześniejsze uczestnictwo uczniów szkół średnich w kursach przygotowawczych [Stokes, 2011, s. 197-224; Osterman, 2011, s. 129-158]. Pomimo wymienionych wyżej realnych korzyści płynących z wykorzystania technologii, instytucje szkolnictwa wyższego nierzadko są dość sceptycznie nastawione do wdrażania nowoczesnych rozwiązań - tym bardziej, że niektórzy badacze zaczynaja kwestionować skuteczność omawianego sposobu redukowania kosztów w perspektywie długookresowej. O ile bowiem technologia pozwala na jednorazowe obniżenie kosztów personelu i infrastruktury, o tyle jej rola w ograniczaniu systematycznie rosnących kosztów edukacji jest zdecydowanie mniejsza [Wolff $\mathrm{i}$ in., 2013, s. 1-21].

Specjalizacja funkcjonalna uczelni to trzeci z wymienionych wcześniej sposobów poprawy efektywności kosztowej. Polega on na dywersyfikacji dostawców usług edukacyjnych przez otwarcie sektora szkolnictwa wyższego dla szerokiego grona podmiotów prywatnych, które w swoich działaniach wykorzystują innowacyjne 
podejścia i koncepcje nakierowane na osiaganie odpowiednich wyników i dbanie o relację jakości do ceny [Rinne, Koivula, 2005, s. 91-123; Parker, 2013, s. 1-25]. Rozwiązanie to jest wykorzystywane przede wszystkim w sytuacji, gdy występuje bardzo duża nadwyżka osób zainteresowanych podjęciem studiów nad możliwościami absorpcyjnymi funkcjonujących szkół wyższych, a w szczególności uczelni publicznych. W Polsce było ono wdrażane w latach dziewięćdziesiątych XX wieku, a jego efektem było powstanie ponad 300 uczelni niepublicznych.

Podsumowując powyższe rozważania należy podkreślić, że realizowanie przez rządy poszczególnych krajów oraz przez poszczególne instytucje szkolnictwa wyższego zasygnalizowanych wyżej działań powinno być dokładnie monitorowane, aby nie spowodowało negatywnych skutków, a w szczególności nie doprowadziło do obniżenia jakości w szkolnictwie wyższym. Warto w tym miejscu przywołać sytuację polegająca na ograniczaniu kosztów personelu poprzez zatrudnianie pracowników na czas określony oraz $\mathrm{w}$ niepełnym wymiarze czasu pracy. Takie rozwiązanie pozwala ograniczyć koszty, ale bez watpienia powoduje spadek zadowolenia u pracowników. W czasach relatywnie dużej mobilności kadry akademickiej, w tym mobilności międzynarodowej, może to utrudnić osiaganie długoterminowych celów strategicznych szkół wyższych i władz publicznych, które dążą do podnoszenia konkurencyjności poszczególnych uczelni oraz konkurencyjności całego sektora szkolnictwa wyższego w porównaniu z innymi krajami.

\section{Pozyskiwanie nowych źródeł finansowania przez instytucje szkolnictwa wyższego}

W większości krajów wysokorozwiniętych uczelnie otrzymują środki na funkcjonowanie głównie ze źródeł publicznych, przy czym ich udział w ostatnich latach systematycznie malał na rzecz źródeł prywatnych. Wynikało to z pozyskiwania przez uczelnie środków w postaci czesnego od studentów i ich rodzin. Ten sposób dywersyfikowania przychodów jest jednak utrudniony w czasach kryzysu gospodarczego, a więc $\mathrm{w}$ okresie, w którym $\mathrm{z}$ uwagi na ograniczone środki publiczne konieczność poszukiwania prywatnych źródeł finansowania staje się szczególnie ważna. Problemy na rynku pracy, będące następstwem spowolnienia gospodarczego, powoduja, że absolwenci szkół średnich mają ograniczone możliwości podjęcia studiów z uwagi na brak wystarczających środków finansowych. Z kolei osoby studiujące, które korzystaja z kredytów i pożyczek studenckich moga mieć problemy z ich spłatą ze względu na trudności w znalezieniu dobrze płatnego zatrudnienia po ukończeniu studiów. Problemy te moga w dalszej perspektywie prowadzić do zaostrzenia przez władze publiczne systemu pomocy finansowej udzielanej studentom, co w rezultacie może spowodować ograniczenie dostępu do studiów. Jest to o tyle istotne, gdyż prowadzone analizy wskazuja, że o dostępie do edukacji na poziomie wyższym w większym stopniu decyduje istnienie i znajomość przez studentów systemu wsparcia finansowego niż poziom czesnego. System ten powinien w szczególności uwzględniać niechęć do podejmowania ryzyka finansowego i awersję do długu przez 
tych, którzy najbardziej potrzebuja wsparcia, czyli osoby pochodzące z rodzin o niższym statusie społeczno-ekonomicznym, które często nie doceniają swoich umiejętności i powattpiewają w możliwość ukończenia studiów [Flacher i in., 2014, s. 8].

Omawiając problematykę pobierania opłat za studia warto zasygnalizować możliwości płynące z pozyskiwania studentów zagranicznych. W wielu krajach uczelnie ustalają bowiem wyższe opłaty za studia dla tych osób, zwiększając i dywersyfikując tym samym przychody z czesnego. Najlepszymi przykładami są Australia i Nowa Zelandia, w których, pomimo wysokich opłat, odsetek studentów zagranicznych zwiększył się w ostatnich latach. Wiele szkół wyższych opracowuje zatem strategie przyciagania studentów zagranicznych, które obejmują działania informacyjne skierowane do konkretnych krajów oraz rozwiązania ułatwiające kształcenie międzynarodowe, w tym wspólne programy studiów. Podejmując próby rekrutowania studentów z innych krajów należy jednak mieć na uwadze to, że zdolność szkół wyższych do internacjonalizacji w dużej mierze zależy od atrakcyjności danego kraju dla studentów zagranicznych. Atrakcyjność ta z kolei jest uwarunkowana szeregiem czynników, takich jak: język, lokalizacja, klimat, polityka imigracyjna itp. [Gopal, 2014, s. 19-21; Immigration..., 2012].

Innym sposobem dywersyfikowania przychodów jest pozyskiwanie środków od przedsiębiorstw. Z reguły przychody powstaja z tytułu świadczenia usług badawczorozwojowych i edukacyjnych na rzecz przedsiębiorstw oraz komercjalizowania wyników badań. Możliwości instytucji edukacyjnych w tym zakresie są zróżnicowane w zależności od przepisów obowiązujących w poszczególnych krajach oraz od profilu poszczególnych instytucji. Szczególnie skuteczne w pozyskiwaniu środków od przedsiębiorstw są uczelnie techniczne, które często świadczą usługi dla przemysłu. Przychody moga też pochodzić z najmu i dzierżawy obiektów należących do uczelni. Bogate doświadczenia w tym aspekcie mają brytyjskie, irlandzkie i australijskie szkoły wyższe. Dla przykładu, Loughborough University (Wielka Brytania) stał się najważniejszym w regionie dostawcą obiektów i urządzeń konferencyjnych oraz obiektów sportowych. Bardziej zaawansowane działania na rynku nieruchomości są podejmowane przez Trinity College (Irlandia), który wynajmuje powierzchnie w najlepszych lokalizacjach, maksymalizując tym samym przychody z najmu, a poza tym nabywa nieruchomości w okresie spadku cen rynkowych, a następnie inwestuje w nie i wynajmuje po odpowiednio wysokich stawkach [Estermann i in., 2011]. Z kolei Macquarie University (Australia) dzierżawi wysokospecjalistyczne laboratoria i pracownie przeznaczone do badania zaburzeń mowy i słuchu. Na uwage zasługuja również możliwości, jakie stwarza rynek kapitałowy, które w szerokim zakresie są wykorzystywane przez uczelnie australijskie emitujące obligacje w celu pozyskania środków na rozwój infrastruktury [Glass, 2014, s. 71]. Z możliwości tej skorzystał także Ohio State University, który jako pierwsza instytucja publiczna w Stanach Zjednoczonych wyemitował obligacje stuletnie [Tobenkin, 2013]. Alternatywne źródła finansowania uczelni moga być też efektem filantropii, choć dotyczy to niemal wyłącznie najlepszych szkół wyższych w Wielkiej Brytanii i Stanach Zjednoczonych [Johnstone, 2004]. 
Działania zmierzające do dywersyfikowania przychodów przez instytucje szkolnictwa wyższego napotykają szereg przeszkód, które z reguły wynikaja z niewłaściwych struktur organizacyjnych i procesów decyzyjnych, utrudniających skuteczną i terminową współpracę $z$ interesariuszami zewnętrznymi oraz dostęp do informacji na temat alternatywnych źródeł finansowania. Ponadto osobom zarządzającym szkołami wyższymi nierzadko brakuje odpowiednich umiejętności i specjalistycznej wiedzy na temat możliwości pozyskiwania nowych źródeł przychodów. W dyskusjach nad możliwościami pozyskiwania przychodów pojawia się też problem ryzyka, które może towarzyszyć nowym źródłom finansowania, a w szczególności ryzyka ograniczenia uczciwości i wolności nauki. Zwraca się zatem uwagę na to, aby działania na rzecz dywersyfikacji przychodów były zgodne z misją uczelni oraz postuluje, aby władze publiczne wpierały te działania - przez tworzenie regulacji prawnych sprzyjających innowacyjnej polityce finansowej szkół wyższych, wprowadzanie zachęt i zwolnień podatkowych, a także rozwijanie umiejętności władz uczelni w zakresie skutecznego różnicowania źródeł finansowania instytucji szkolnictwa wyższego [Glass, 2014, s. 74].

\section{Przyszłość finansowania instytucji szkolnictwa wyższego w Polsce}

Dotychczasowe obserwacje pozwalają stwierdzić, że podstawowym sposobem redukowania kosztów w polskim systemie szkolnictwa wyższego była specjalizacja funkcjonalna uczelni, w rezultacie której powstało kilkaset uczelni niepublicznych, natomiast sposobem pozyskiwania nowych przychodów było przede wszystkim pobieranie opłat za studia. Wspomniana specjalizacja uczelni traci uzasadnienie w aktualnych uwarunkowaniach demograficznych, gdy możliwości absorpcyjne funkcjonujących w Polsce publicznych szkół wyższych są, generalnie rzecz biorąc (nie rozpatrując możliwości absorpcyjnych w odniesieniu do poszczególnych kierunków studiów), zbliżone, a niekiedy nawet większe od liczby osób zainteresowanych podjęciem studiów. W tej sytuacji sposobów na poprawę efektywności kosztowej instytucje szkolnictwa wyższego powinny upatrywać w wykorzystaniu, na szerszą skalę niż do tej pory, nowoczesnych rozwiązań technologicznych. Wiele wskazuje też na to, że w najbliższych latach rząd zintensyfikuje działania zachęcające uczelnie publiczne do łączenia się, co tym samym pozwoliłoby na zmniejszenie kosztów administracyjnych. Ponadto można spodziewać się, że kolejne regulacje prawne dotyczące podziału dotacji z budżetu państwa dla uczelni będą w coraz większym stopniu opierały się na kryterium wydajności, uwzględniając tym samym wyniki uzyskiwanie przez szkoły wyższe.

Z danych statystycznych publikowanych przez GUS wynika, że udział opłat za studia $\mathrm{w}$ przychodach polskich uczelni systematycznie maleje. Lukę finansowa w tym zakresie mogłyby, w pewnym stopniu, wypełnić opłaty pobierane za studia podyplomowe, kursy i szkolenia, a nade wszystko opłaty uzyskiwane od studentów zagranicznych. Mimo że Polska nie jest tak atrakcyjna jak kraje anglojęzyczne oraz państwa leżące w zachodniej i południowej części Europy, to jednak doświadczenia 
uczelni medycznych potwierdzają rosnącą zdolność polskich szkół wyższych do internacjonalizacji. Równie ważne wydają się być możliwości płynące ze świadczenia usług badawczo-rozwojowych dla przedsiębiorstw, które w tej chwili są w relatywnie największym stopniu wykorzystywane przez uczelnie techniczne. Pozyskiwanie przez polskie szkoły wyższe przychodów z rynku kapitałowego to jeszcze w dużej mierze zagadnienie abstrakcyjne, ale możliwości generowane przez rynek nieruchomości sa jak najbardziej realne, a jednocześnie mało doceniane. Doświadczenia krajów wysoko rozwiniętych, a w szczególności krajów anglosaskich, pozwalaja jednak przypuszczać, że przychody z najmu i dzierżawy należących do szkół wyższych obiektów o najlepszej lokalizacji oraz obiektów wysokospecjalistycznych będą miały w przyszłości większe znaczenie.

\section{Podsumowanie}

Rozważania będące przedmiotem niniejszego artykułu pozwalają pozytywnie zweryfikować postawioną hipotezę. Pomimo różnic społecznych, gospodarczych, kulturowych i politycznych między poszczególnymi krajami wyzwania finansowe stojące przed instytucjami szkolnictwa wyższego są bardzo podobne. Autorzy licznych raportów i opracowań zwracaja uwagę na potrzebę zwiększenia autonomii szkół wyższych w zarządzaniu zasobami finansowymi, zapewnienie korelacji między wynikami osiaganymi przez uczelnie a przyznanymi środkami, poprawę efektywności systemów zarządzania finansowego, a w szczególności redukowanie kosztów i pozyskiwanie nowych źródeł finansowania. Ponadto decydenci polityczni oczekuja, że fundusze publiczne przekazywane uczelniom przyczynią się do osiagania strategicznych celów polityki społeczno-gospodarczej państwa. Nie bez znaczenia jest też rosnąca rola prywatnych źródeł finansowania, która sprawia, że szkoły wyższe zaczynają bardziej przypominać instytucje prywatne niż publiczne, a zarządzanie systemami szkolnictwa wyższego przez władze publiczne staje się coraz bardziej skomplikowane [Erina, Erins, 2015, s. 186; Johnstone, 2014]. W świetle przedstawionych informacji można też stwierdzić, że dążąc do poprawy systemu finansowania instytucji szkolnictwa wyższego w Polsce należy w pewnym stopniu czerpać z bogatych doświadczeń krajów wysoko rozwiniętych. Doświadczenia te wskazują bowiem na konieczność wprowadzenia pewnych zmian w finansowaniu uczelni, a jednocześnie nakreślają kierunek, w którym prawdopodobnie będzie zmierzał system finansowania. Należy jednak pamiętać, że niemożliwe jest ustalenie optymalnego poziomu finansowania, a także mieć na uwadze fakt, że finansowanie nie jest jedynym wyznacznikiem jakości edukacji na poziomie wyższym. Istotną rolę odgrywa bowiem organizacja i sposób zarządzania w szkolnictwie wyższym. 


\section{Literatura}

Askling B., 1997, Quality Monitoring as an Institutional Enterprise, "Quality in Higher Education", vol. 3(1), DOI: 10.1080/1353832960030103.

Bowen W.G., 2013, Higher Education in the Digital Age, Princeton University Press, Princeton.

Employment control framework for the bigher education sector 2011-2014, https://bit.ly/ 2LKiYYF [data wejścia: 21.01.2018].

Erina J., Erins I., 2015, Assessment of Higher Education Financing Models in the CEE Countries, "Procedia - Social and Behavioral Sciences", vol. 177, DOI: 10.1016/ j.sbspro.2015.02.379.

Estermann T., Bennetot Pruvot E., 2011, Financially Sustainable Universities II: European Universities Diversifying Income Streams, European University Association, Brussels.

Flacher D., Harari-Kermadec H., Moulin L., 2014, Financing Higher Education: a contributory education scheme, Document de treball de l'IEB 2013/34, University of Barcelona, Barcelona.

Glass A. (ed.), 2014, The State of Higher Education 2014, OECD Publishing.

Gopal A., 2014, Canada's Immigration Policies to Attract International Students, "International Higher Education", no. 75, DOI: 10.6017/ihe.2014.75.5435.

Immigration of International Students to the EU. European Migration Network Study 2012, https://bit.ly/2snSUdx [data wejścia: 21.01.2018].

Improving Post-Secondary Education Through the Budget Process: Challenges and Opportunities 2013, https://bit.ly/2Lg74Vt [data wejścia: 20.01.2018].

Johnstone D.B., 2004, University Revenue Diversification Through Philanthropy: International Perspectives, https://bit.ly/2Joh2qn [data wejścia: 20.01.2018].

Johnstone D.B., 2014, Financing Higher Education: Worldwide Perspectives and Policy Options, https://bit.ly/2LPuXnU [data wejścia: 19.01.2018].

Osterman P., 2011, The Promise, Performance and Policies of Community Colleges, [in:] Reinventing Higher Education. The Promise of Innovation, Wildavsky B., Kelly A.P., Carey K. (eds), Harvard Education Press, Cambridge.

Parker L.D., 2013, Contemporary University Strategising: The Financial Imperative, "Financial Accountability \& Management", vol. 29(1), DOI: 10.1111/faam.12000.

Promoting Research Excellence: Latest OECD Insights, 2014, OECD Publishing, Paris.

Rinne R., Koivula J., 2005, The Changing Place of the University and a Clash of V alues: The Entrepreneurial University in the European Knowledge Society, "Higher Education Management and Policy", vol. 17(3), DOI: 10.1787/hemp-v17-3-en.

Salmi J., 2009, Scenarios for Financial Sustainability in Tertiary Education, [in:] Higher Education to 2030. vol. 2. Globalisation, Educational Research and Innovation, OECD Publishing, Paris.

Sheets R., Crawford S., Soares L., 2012, Rethinking Higher Education Business Models. Steps Towards a Disruptive Innovation Approach to Understanding and Improving Higher Education Outcomes, https://ampr.gs/2JjUib0 [data wjeścia: 21.01.2018].

Staying on top: The challenge of sustaining world-class higher education in the UK, 2010, https:/ /bit.ly/2LdoaDf [data wjeścia: 21.01.2018]. 
Stokes P., 2011, What Online Learning Can Teach Us about Higher Education, [in:] Reinventing Higher Education. The Promise of Innovation, Wildavsky B., Kelly A.P., Carey K. (eds), Harvard Education Press, Cambridge.

Tobenkin D., 2013, Revenue Refill, https://bit.ly/2JiiQ46 [data wejścia: 19.01.2018].

Truger A., Will H., 2012, The German 'debt brake' - a shining example for European fiscal policy?, Working Paper no. 15, Berlin School of Economics and Law, Berlin.

Wolff E.N., Baumol W.J., Saini A.N., 2013, A Comparative Analysis of Education Costs and Outcomes: The United States vs. Other OECD Countries, "Economics of Education Review", vol. 39, DOI: 10.1016/j.econedurev.2013.12.002. 